\title{
V. The Preliminary Reference Procedure as an Instrument of Judicial Dialogue in the EU - the CEE Perspective
}

Anna Czaplińska*

\section{Introduction}

The general aim of the research project "International law through the national prism: the impact of judicial dialogue" was to deepen the understanding of how courts engage in the interpretation, application and development of international law through transnational judicial dialogue. The dialogue is thus regarded as a tool that may serve well the development of the international legal order and the strengthening of the rule of law within it by domestic and international courts.

For purposes of the research project, judicial dialogue was defined extensively, as any reference, whether affirmative or critical, by one court to the jurisprudence of another concerning, of course, questions of international law. Such 'indirect dialogue' is the prevailing form of interaction available to most national and international courts. This is the case because within the framework of international legal order or its particular regimes there exist usually no formal

* Dr iur., Assistant Professor, Department of European Constitutional Law, Faculty of Law and Administration, University of Lodz, Poland. 
mechanisms enabling a 'direct dialogue', understood as a dialogue involving contact and exchange of views, between domestic and foreign or international courts on a given legal problem. ${ }^{1}$ The European Union makes the most significant exception in that respect. ${ }^{2}$

One issue needs to be clarified at the very beginning of this analysis. For the purposes of the present paper, but also generally in the author's view, EU law is regarded as a part of international law, created by Member States of an international organization and the organization itself. Despite some particular characteristics (which themselves also originate from concepts of international law, as e.g. direct effect and primacy are derived from monist theories) and a certain extent of autonomy, the EU legal order can only be described as an autonomous regime, a subsystem of international law. As such, it comes within the substantial scope of the present research project.

Moreover, among these particular features of the EU legal order there are factors determining the phenomenon of judicial dialogue in the European Union. One of them is the establishment of a judicial organ of the organization, which, nowadays, has become a whole system of judicial bodies functioning under the name of "the Court of Justice of the European Union" (CJEU). It holds compulsory jurisdiction over the EU, its Member States and institutions with a competence to "ensure that in the interpretation and application of the Treaties the law is observed" (Art. 19 TEU). The other feature is the inclusion in this judicial system of Member States' domestic courts as guardians of effectiveness of EU law on the national level, substantially as a consequence of direct effect and other principles of EU law and formally through the establishment of a procedural mechanism generating the direct judicial dialogue on EU law between the national courts and the CJEU: the preliminary reference procedure (Art. 267 TFEU). ${ }^{3}$

Thus, there is no controversy in stating that by founding the European Communities, which then evolved into the present European Union, the Member States had created a legal system where judicial dialogue was, from the outset, an inherent instrument for development of law. ${ }^{4}$ However, the literature, which examines, explicitly or implicitly, the topics of preliminary reference and of EU legal order development in the context of judicial dialogue is rather sparse. ${ }^{5}$ Therefore, it was

1 For some instances other than the EU see: R. Virzo, 'The Preliminary Ruling Procedures at International Regional Courts and Tribunals' (2011) 10 The Law and Practice of International Courts and Tribunals, p. 285.

2 See: A. Arnull, 'Judicial Dialogue in the European Union', [in:] J. Dickinson, P. Eleftheriadis (eds), Philosophical Foundations of European Union Law (Oxford University Press 2012), p. 118.

3 Farrell A. Miller, 'The Preliminary Reference Procedure of the Court of Justice of the European Communities: A Model for the ICJ' (2009) 32 Hastings International and Comparative Law Review, p. 677.

4 See: F. Jacobs, 'Judicial dialogue and the Cross-Fertilization of Legal Systems: the European Court of Justice' (2003) 38 Texas International Law Journal, p. 548.

5 Alongside the works already cited we may mention: J. Cohen, 'The European Preliminary Reference and the US Supreme Court Review of State Court Judgments: A Study in Comparative 
considered worthy to include this issue into the research project. As the result, the present paper examines the CJEU jurisprudence, which results from preliminary reference practice of four of the Central and East European EU Member States, which are examined in this research project, namely the Czech Republic, Hungary, Lithuania and Poland. The examination includes rulings issued in a period from their EU accession (1 May 2004) until 14 February 2016.

It needs to be stated that the task of identification of preliminary reference cases coming from the four Member States was not a very hard one, thanks to the CJEU jurisprudence database and the research tools provided there. The multilingual character of the EU, reflected inter alia in the obligation to publish the documents of general application in all official languages of the Union, ${ }^{6}$ is retained also in respect to the CJEU. ${ }^{7}$ The publication of the CJEU judgments in all EU languages and of the orders at least in French and the language of proceedings, made it possible for such research to be conducted by a single person in a comparative way. This also confirms the crucial role that linguistic availability plays in any study involving empirical examination of case law of international and - especially - national courts. In the effect, over two hundred twenty cases of preliminary rulings on references stemming from the four States were identified. ${ }^{8}$ Only cases closed within the research period were taken into consideration.

If the matter of judicial dialogue is to be regarded purely technically, each of the over two hundred identified cases constitutes an instance of a dialogue: there is a question on a legal issue and then there is a reply. However, the present study focuses on the substance of such dialogue and its relevance for the evolution

Judicial Federalism' (1996) 44 AJIL, p. 421; G. Martinico, O. Pollicino, The Interaction between Europe's Legal Systems. Judicial Dialogue and the Creation of Supranational Laws (Edward Elgar Publishing 2012); M. Cartabia, 'Taking Dialogue Seriously The Renewed Need for a Judicial Dialogue at the Time of Constitutional Activism in the European Union' (2007) 12 Jean Monnet Working Papers; M. Claes, M. de Visser, 'Are You Networked Yet? On Dialogues in European Judicial Networks' (2012) 8 Utrecht Law Review, p. 100; R.D. Kelemen, 'The Court of Justice of The European Union in The Twenty-First Century' (2016) 79 Law and Contemporary Problems, p. 117; C. Carruba, L. Murrah 'Legal Integration and Use of the Preliminary Ruling Process in the European Union' (2005) 59 International Organization, p. 399. For critical assessment of the 'dialogue' concept see: K. Alter, Establishing the Supremacy of European Law: The Making of an International Rule of Law in Europe (Oxford University Press 2001), p. 38; A. Dyevre, 'Domestic Judicial Non-Compliance in the European Union: A Political Economic Approach' (2013) 2 LSE Law, Society, Economy Working Papers.

6 Art. 4 of Regulation No. 1 determining the languages to be used by the European Economic Community, O.J. 171958 385, last amended by Council Regulation (EU) 517/2013 of 13 May 2013, O.J. L 15820131.

7 Arts. 36-40, Rules of Procedure of the Court of Justice of 25 September 2012 (O.J. L 265, 29.9.2012), as amended on 18 June 2013, O.J. L 173201365.

8 The aim of the research was not to provide statistical information and no statistical methods are used. However, we refer to the numbers, usually in approximate way just to show the total amount and particular share of each State, the diversification of subject matter of references and the interplay between amount and significance of references. 
of EU legal order. Thus preliminary rulings are subject to a thorough analysis as to whether and how they contribute to the development of EU law, whether and how they strengthen the rule of law and influence the protection of individual rights within the European Union, whether they concern legal problems of universal character, of interest to more Member States (and not just to the referring State) and are likely to be generally followed and finally - whether they involve a more extensive argumentation of the courts that would enhance the quality of the dialogue. The result of this analysis is the selection of the most significant preliminary rulings, which are further discussed in the present paper.

It was not possible to examine the follow-up to the CJEU preliminary rulings at the national courts within the framework of the present study. Due to limitations of languages and accessibility, such task would have gone beyond the capacity of a sole researcher and would require engagement of a team of scholars. Moreover, the issue of judicial dialogue in respect of EU law may be regarded as a separate subject of research, and, as such, it definitively deserves a comprehensive study (as mentioned earlier, it is rather underexploited in the doctrine). Here, only some aspects have been considered in a limited way and with a focus on the selected CEE States just as one of complementary topics within a more complex research project.

\section{The Dialogue-generating Features of the Preliminary Reference Procedure}

For the purposes of the present study it is neither necessary to describe in detail the preliminary reference procedure, nor useful to discuss all legal problems linked with it. In fact, there are numerous handbooks, monographs and articles dealing with the procedure in general as well as with specific issues. ${ }^{9}$ Therefore, we shall refer to the contents of Art. 267 TFEU only in general terms and focus on these features of the procedure, which determine its discursive nature.

According to Art. 267, any court (or tribunal) of a Member State may refer to the CJEU any question raised in a case before it concerning interpretation of the Treaties, or interpretation or validity of acts of the EU institutions or other EU bodies, if such a court considers a ruling on this question necessary for a judgment in a specific case. Where a court against whose decisions there is no judicial remedy under national law decides a case, that court is under obligation to refer the matter to the CJEU. However, this obligation arises only when the referring

9 For recent comprehensive presentation see: M. Broberg, N. Fergen, Preliminary References to the European Court of Justice (Oxford University Press 2014). 
court first regards the reply to be indispensable for deciding a case. The CJEU preliminary ruling, given in reply to the national court's reference, is binding upon that court, since "the aim of judicial cooperation between national courts and the Court of Justice under Article 177 [present Art. 267] is to ensure that community law is applied in a unified manner throughout the Member States."10 Moreover, in accordance with the settled case law of the CJEU, the preliminary rulings have also erga omnes effect, binding on courts other than the referring court in a sense that those courts cannot ignore the CJEU ruling, but they may either follow it or decide to make on their own another preliminary reference concerning the same problem. ${ }^{11}$

The occasionally compulsory character of references and the (individually and generally) binding force of preliminary rulings provide the basic arguments for denying the discursive nature of the preliminary reference procedure. ${ }^{12}$ According to this position, one might speak about 'judicial dialogue' only when the interaction between courts is voluntary and there is no relation of subordination, dependency or even reliance between them. However, acceptance of such argumentation would lead to denial of the 'dialogue' quality in many cases of institutionalized judicial interaction. Yet, this is actually the matter of defining judicial dialogue and, of course, each researcher is free to determine the subject of his/ hers research. As stated earlier, within the present project the broadest possible approach to judicial dialogue is adopted. ${ }^{13}$ Our interests are focused on the fact that one court having faced a legal problem, which it needs to solve, is seeking the opinion of another court, of an international or foreign court, concerning the same or similar problem, and on the outcome of such interaction between the courts. From this perspective it does not matter whether such reference to other jurisdiction is direct, induced by a procedural requirement, consists in posing a question to have it answered by the other court or indirect, made of free choice (if not on an impulse) and often reduced to a random quotation of the other court's judgment.

M. Claes and M. de Visser present another argument for the denial of the discursive character of the preliminary reference procedure. They refuse to qualify it as a 'real' judicial dialogue and stress the lack of a 'discussion' between

10 Case 69/85 Wünsche Handelsgesellschaft GmbH \& Co. v Federal Republic of Germany (order, 5 March 1986), paras 12-13.

11 A. Farrell Miller, 'The Preliminary Reference Procedure of the Court of Justice of the European Communities: A Model for the ICJ', pp. 676-677. For detailed analysis of preliminary ruling effects see: M. Broberg, N. Fergen (n. 10), p. 441 and the case law quoted there.

12 This line of argumentation was invoked e.g. in a presentation of $\mathrm{Ch}$. Fardet during the international colloquy La concurrence des juges en Europe - le dialogue en question(s) (Tours, 25-27 November 2015), and in the discussions hereinafter. The author participated in the colloquy. The video records of the colloquy are available at: $<$ https://juges-en-europe.sciencesconf.org/resource/page/id/10> (access: 10 June 2016).

13 See in that respect the text of A. Wyrozumska in the present volume. 
the CJEU and the referring court in the course of proceedings. ${ }^{14}$ Claes and de Visser claim that, on one hand, the role of referring court is restricted to posing the question and to the application of the CJEU's answer and, on the other, that the CJEU rulings are variable and unpredictable and thus sometimes not very useful for the national courts. ${ }^{15}$ There are, however, some contradictions in their argumentation. It seems that the authors would recognize as judicial dialogue only a situation where a direct multiple exchange of views between the courts or judges takes place. It is, however, impossible to introduce such discussions between the courts in any judicial proceedings, especially if foreign or international courts were to be involved. The narrowing of the understanding of judicial dialogue would also result in leaving the indirect dialogue outside of the scope of definition of judicial dialogue. These would be situations where one court merely refers to case law of another court, usually without the latter's knowledge of the fact and the possibility to react. Furthermore, there are procedural means provided for in the CJEU's Rules of procedure serving the increase, if necessary, of the involvement of the referring court in the CJEU deliberations. These are a request for clarification from the CJEU to the referring court (Art. 101) and the possibility of making subsequent references to the CJEU, if the national court decides that further guidance is required (Art. 104). The fact that national courts do not avail themselves of these subsequent references very often indicates rather that CJEU's preliminary rulings usually are sufficiently clear and useful for the national courts. Interestingly, Claes and de Visser take notice of these regulations (in a footnote) but consider them not significant enough to affect their allegations and understanding of the notion of a dialogue. ${ }^{16} \mathrm{It}$ is also hard to understand why the variability and unpredictability of CJEU's decisions would question the discursive character of preliminary reference procedure. In other words, why refer a question, if one may predict the result? The capacity to anticipate the answer does not seem to be a feature that induces the dialogue; it seems more like the one preventing it.

Last but not least, there is a point where the two positions contesting the dialogic nature of preliminary reference procedure clash. According to the former view, there can be no dialogue if the national court is obliged to make a reference. According to the latter, one cannot speak about dialogue in the context of preliminary reference procedure, if it is so easy to avoid such dialogue by simply not making a reference. ${ }^{17}$ Actually, if all these arguments were to be taken seriously, we would have to assume an opinion that no such thing as judicial dialogue exists

14 M. Claes, M. de Visser, 'Are You Networked Yet? On Dialogues in European Judicial Networks', p. 104. They refer to the dialogue typology by L. Tremblay in 'The Legitimacy of Judicial Review: The Limits of Dialogue between Courts and Legislatures' (2005) 3 International Journal of Constitutional Law, p. 617.

16 Ibidem.

17 Ibidem, p. 104. 
in practice, not only in respect of preliminary reference procedure, but at all. And this is the main danger that may result from narrowing down the definitions of judicial dialogue.

In our view, many of the features argued above as disqualifying the discursive nature of the preliminary reference procedure are in fact confirming it. But maybe the last word on this issue should be given to the actor concerned, the CJEU alone. In 2008 the Court gave preliminary ruling in the German case Kempter. ${ }^{18}$ The case concerned interpretation of the CJEU judgment Kühne \& Heitz $z^{19}$ as to whether in order to contest a final administrative decision on the basis of the Kühne \& Heitz rules, the party concerned must have had first raised the issue of EU law in the earlier proceedings before national court, which disregarded such issue at that time and, having issued a judgement without a reference to the CJEU, made the contested administrative decision final. ${ }^{20}$ The CJEU ruled, quite predictably, that no such requirement could be derived from the Kühne \& Heitz judgment. In its reasoning the Court expressly stated that "the system of references for a preliminary ruling is based on a dialogue between one court and another, the initiation of which depends entirely on the national court's assessment as to whether a reference is appropriate and necessary". The Court agreed in that respect with the opinion of Advocate General Y. Bot. ${ }^{21}$ The Advocate General recalled the existing CJEU case law, originating from the Cilfit judgement, ${ }^{22}$ concerning the scope of obligation of national courts of last instance to make a preliminary reference including the situations where national courts might be exempted from the obligation. He concluded, and this position was subsequently adopted by the CJEU (as quoted above), that the decision to make or not to make a reference for a preliminary ruling depended entirely on a national court's assessment and in no way depended on the pleas of the parties to the main proceedings. Both the Advocate General and the CJEU consider this freedom of assessment as to the necessity of a reference as a dialogue-generating feature of the preliminary ruling procedure. ${ }^{23}$ Of equal relevance is the discretionary power of a national court to decide whether it obtained sufficient guidance from the preliminary ruling delivered in response to its reference or whether it would be necessary to refer to the CJEU on the matter again. ${ }^{24}$

18 Case C-2/06 Willy Kempter KG v Hauptzollamt Hamburg-Jonas (CJEU, 12 February 2008), para. 42.

19 Case C-453/00 Kühne \& Heitz NV v Produktschap voor Pluimvee en Eieren (CJEU, 13 January 2004).

20 Case C-2/06 Kempter judgement, para. 21.

21 Case C-2/06 Willy Kempter KG v Hauptzollamt Hamburg-Jonas (Advocate General Y. Bot opinion, 24 April 2007), paras 99-104.

22 Case 283/81 Srl CILFIT and Lanificio di Gavardo SpA v Ministry of Health (CJEU, 6 October 1982).

23 See also: N. Fennely, 'Preliminary Reference Procedure: A Factual and Legal Review' (2006) 13 Irish Journal of European Law, p. 72.

24 Case C-2/06 Kempter opinion, para. 101. 
Just a couple of months later the CJEU confirmed the dialogic character of preliminary reference procedure in the Hungarian case Cartesio, which is actually one of the most significant examples of contribution of the CEE Member States preliminary reference practice to the development of EU law. ${ }^{25}$ The case concerned several legal issues, which are considered below in a more detailed way. Thus, at this point it is sufficient to mention that the discursive nature of preliminary reference system is indicated here on the occasion of examination, whether a measure of domestic law providing the possibility to appeal against a national court's decision on making a preliminary reference to the CJEU (existing under Hungarian law) could limit the national court's power to make such reference stemming directly from Art. 267 TFEU if, in appeal proceedings, the superior court might amend the decision, declare the request for a preliminary ruling inoperative and order the referring court to resume the suspended proceedings before it. The CJEU stated that, although EU law did not generally preclude a decision on preliminary reference from remaining subject to the remedies normally available under national law (including appeal), nevertheless, the outcome of such a remedy could not limit the jurisdiction conferred by Art. 267 TFEU to national court to make a reference to the CJEU, because the assessment of the relevance and necessity of the question was the responsibility of the referring court alone (subject only to the limited verification by the CJEU). ${ }^{26}$ Therefore, only the referring court may decide, taking into account the appeal outcome, whether to maintain the preliminary reference, amend it or withdraw. ${ }^{27}$ Thus, the discretion of the national court was reaffirmed as a factor relevant for the dialogue character of preliminary reference procedure.

The scope of discretion on the part of the CJEU is equally relevant for elaborating the court-to-court dialogue within the preliminary reference procedure. As T. Tridimas rightly points out, the Court, while exercising its functions under Art. 267 TFEU, enjoys a significant range of discretion, that manifests itself in a number of respects. ${ }^{28}$ First, the CJEU is free to assess whether the referring court provided information sufficient to give the preliminary ruling and, if necessary, request clarification or dismiss the request. It may well decide to refuse to give the answer when it finds the question does not in fact concern issues of EU law or is hypothetical. ${ }^{29}$ However, the Court has wide discretionary powers when it comes to evaluation of factual and legal background presented

25 Case C-210/06 Cartesio Oktató és Szolgáltató bt (CJEU, judgement, 16 December 2008), para. 91.

28 T. Tridimas, 'The CJEU and the Specifity of Preliminary Reference Rulings: Some Reflections', [in:] S. Besson, P. Pichonnaz (eds), Les principes de droit européen - Principles in European Law (L.G.D.J. 2011), p. 332.

29 See: ibidem, 332-333 and the CJEU case law quoted there: N. Fennely (n. 24), p. 72. 
by a national court, which may even result in reformulation of the questions referred or in taking into consideration other EU rules and provisions than those, to which the national court refers. All that is put in place in order to provide the national court with the best possible knowledge that would be helpful for deciding the case pending before it. ${ }^{30}$ The reformulation technique is particularly useful where a referring court phrased its question expressly in terms of compatibility of national provisions with EU law. This is a question, in line with the standing jurisprudence of the CJEU, on which only the national court is competent to decide, even though this is done on the basis of EU law interpretation given by the CJEU. ${ }^{31}$

Another factor determining the dialogic character of the preliminary reference procedure is the lack of any hierarchical relationship between the CJEU and national courts. ${ }^{32}$ The CJEU is neither appellate instance for domestic courts, nor has jurisdiction to examine and repeal national regulations. The binding effects of preliminary rulings are limited to the explanation of issues of EU law (concerning its interpretation or validity) referred to the CJEU. ${ }^{33}$ They do not settle the case pending before the national court, but as stated above, provide answers necessary for deciding the case by this court. It is only a referring national court alone that is competent to assess whether, and how, the obtained preliminary ruling may be applied to the factual and legal circumstances of the given case.

The quality of the judicial dialogue within the preliminary reference procedure depends, on the one hand, on the extent and accuracy of information given by a national court on facts and legal background of the proceedings in respect to which the reference is made. On the other hand, it is determined by the specificity of the preliminary ruling delivered by the CJEU. A proposal by Tridimas is to distinguish a three-degree scale of specificity of preliminary rulings: ${ }^{34}$ the 'outcome cases' where the CJEU suggests a ready solution to the dispute before national court; ${ }^{35}$ 'guidance cases' where the CJEU provides guidelines to a national court on how to resolve the case; ${ }^{36}$ and 'deference cases' where the CJEU answers in such general terms that it leaves it to a national court to decide on the issue. ${ }^{37}$ Although this classification aims to demonstrate how much the degree of specificity and the margin of discretion left to national courts may vary in respect to different preliminary rulings, it appears not very useful in practice. Its author himself states that the thresholds of the categories are somewhat

\footnotetext{
30 Ibidem. See also: M. Broberg, N. Fergen (n. 10), p. 362.

31 Ibidem, p. 412. See also: A. Arnull (n. 3), p. 118.

32 See: F. Jacobs (n. 5), p. 548; A. Dyevre (n. 6), p. 9.

33 M. Broberg, N. Fergen (n. 10), p. 441.

34 T. Tridimas (n. 29), p. 333.

35 Ibidem, p. 334.

36 Ibidem, p. 336.

37 Ibidem, p. 340.
} 
floating and they may coexist in the same ruling. ${ }^{38}$ Probably the biggest weakness of Tridimas' approach lies in the fact that his typology is elaborated on the basis of criteria applied in abstracto to the CJEU preliminary rulings without any connection to the follow up and final outcome of their application by the national courts. Therefore, instead of multiplying categories it may be more reasonable to state that the degree of specificity of preliminary rulings may vary from case to case, but it is related above all to the subject of the questions and the specificity of information referred to the CJEU by a national court. It is the interplay of the different aspects of discretion, interdependence and reliance on the part of both, the CJEU and the national courts that make the preliminary reference system the best example of a direct judicial dialogue. These factors surface also in the cases examined within the present study.

\section{The Preliminary Reference Practice of the Courts in the Selected CEE Member States and Its Impact on the Development of EU Law}

\subsection{The Czech Republic}

Within the research period the CJEU responded to thirty-four preliminary references submitted by the Czech courts (and further four were withdrawn by the national referring court). Just one reference within the set was declared inadmissible, although it has to be stressed that such outcome of the case does not automatically exclude its potential contribution to the development of EU law. It is not so uncommon that a reference, which finally turns out to be inadmissible, gives rise to legal problems, which are explained by the CJEU in an order dismissing the reference.

The Supreme Administrative Court (Nejvyšši správní soud) submitted about the half of the cases. In addition, some of the remaining references came from the administrative divisions of provincial courts (Krajský soud). Thus the question of application of EU law in relations between an individual and Member State authorities clearly prevails in the Czech preliminary reference practice.

Interestingly, one of the first cases referred to by a Czech court to the CJEU turned out to become a landmark case in the jurisprudence on the principle of legal certainty. It is the famous Skoma-Lux (I) case. ${ }^{39}$ Skoma-Lux was a Czech com-

38 Ibidem, p. 334.

39 Case C-161/06 Skoma-Lux sro v Celní reditelství Olomouc (CJEU, 11 December 2007). 
pany (specializing in international wine and liquor trading), which brought to the Provincial Court (Krajský soud) in Ostrava an action for annulment of several decisions of Czech customs authorities imposing fines for alleged infringements of certain customs provisions of Czech law, as well as EC Regulation 2454/93. The alleged offences were supposed to occur several times between 11 March and 20 May 2004 (so before and after the accession of the Czech Republic to the EU). The company based its action (in the part concerning the EU law) on the plea of inapplicability of the Union regulation to the alleged offences, including those which occurred after the accession of the Czech Republic to the EU, as on the dates when the acts in dispute were committed that regulation had not yet been published in the Czech language in the Official Journal of the European Union. ${ }^{40}$ So the national court referred to the CJEU questions concerning the case, of which the essential one read:

May Article 58 of the Act concerning the conditions of accession, on the basis of which the Czech Republic became a Member State of the European Union as from 1 May 2004, be interpreted as meaning that a Member State may apply against an individual a regulation which at the time of its application has not been properly published in the Official Journal of the European Union in the official language of that Member State?

The first noticeable symptoms of the importance of the case were, firstly, the fact that it was decided by the Grand Chamber and, secondly, that there was quite a broad interest among other Member States, which eventually intervened in the proceedings ${ }^{41}$ Such factors at first sight, though they do not grant that the outcome, will meet the expectations, indicate that one may suspect a given case of having potential for significant influence on the development of EU law. However, what we shall focus on in the present paper is the discursive aspect of the preliminary ruling. It is remarkable how carefully the referring court considered the problem in the light of the CJEU previous case law concerning the publication of EU legal acts. ${ }^{42}$ It pointed out to the Oryzomyli judgment where the Court stated that the absence of proper publication of a Community act in the Official Journal could constitute a ground for its unenforceability against individuals. ${ }^{43}$ Regarding circumstances of the case in the main proceedings, the referring court stressed that the provisional translations of the regulation were available on the internet (on EU and Czech Ministry of Finance websites), and noticed that interested parties usually acquaint themselves with legal rules in an electronic form. The absence of publication in the Official Journal then would not always

\footnotetext{
40 Ibidem, para. 14.

41 These were - besides of course the Czech government and the Commission - the Estonian, Latvian, Polish, Slovak and Swedish governments.

42 Case C-161/06 Skoma-Lux, paras 18-21.

43 Case 160/84 Oryzomyli Kavallas and Others (CJEU, 15 May 1986), paras 11-21.
} 
result in factual unavailability of the content of a legal act. ${ }^{44}$ Therefore, a possible solution to the problem might involve the acceptance that the applicability of EU legislation not published in the relevant language should be determined on a case-by-case basis, examining whether an individual concerned had a possibility of getting to know the content of the act. In case of Skoma-Lux such finding would lead to an assumption that as a company operating internationally it had to be aware of the customs rules known in all Member States. However, the referring court further observed that the formal requirement of a proper publication of legislation in an official language of a person to whom it applies is one of the basic safeguards for observance of the principles of legal certainty and equality of citizens, confirmed by the CJEU case law, and that the parallel existence of a number of non-official divergent translations would increase legal uncertainty. ${ }^{45}$ Precisely the principles of legal certainty and equal treatment of individuals within the scope of EU law were the two major grounds that the CJEU relied on in its ruling. The Court emphasized that although Community legislation was indeed available on Internet in that form and used by individuals more and more frequently, it was not equivalent to a valid publication in the Official Journal in the absence of any rules in that regard in EU law. ${ }^{46}$ Thus, the CJEU could not accept such form of making EU legislation available to be a sufficient basis for the enforceability of provisions. The Court confirmed that the only authentic version of an EU regulation was that in the Official Journal of the European Union. ${ }^{47}$ Consequently, the CJEU ruled that Art. 58 of the Act concerning the conditions of accession "precluded the obligations contained in Community legislation which has not been published in the Official Journal of the European Union in the language of a new Member State, where that language is an official language of the Union, from being imposed on individuals in that State, even though those persons could have learned of that legislation by other means." ${ }^{48}$ The reply given to the provincial court's reference was thus unequivocal, leaving no space for doubt on the part of the referring court as to how to apply this interpretation to the pending case. As a late development that partly might have originated in the Skoma-Lux case one may regard the adoption of Council Regulation (EU) No. 216/2013 of 7 March 2013 on the electronic publication of the Official Journal of the European Union, ${ }^{49}$ which granted equal status to the printed and the electronic version of Official Journal as means for official publication of EU legislation. Its enactment, however, would not change the situation in Skoma-Lux, as the Regulation considers as authentic only the electronic version of Official Journal and no other sources available on the Internet.

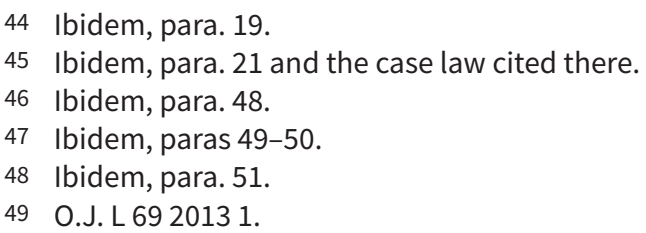


Just by a pure chance, the two probably most famous Czech preliminary ruling cases (Skoma-Lux being the first one) are also significant in respect of judicial dialogue. Although in the case of the second one - the Landtová ruling ${ }^{50}$ - what started as an attempt of dialogue ended up as a multilevel, multidimensional inter-court dispute. ${ }^{51}$ The essential legal issue of the case before the Czech courts originated in the dissolution of Czechoslovakia (which effected on 1 January 1993) and the measures agreed and adopted by the two new States to deal with various problems resulting from the dissolution. One of them was the Agreement on Social Security of 29 October 1992 between the Czech Republic and the Slovak Republic, which in its Art. 20(1) settled the rule for recognition of social insurance periods. ${ }^{52}$ As a result the benefits were to be calculated according to the rules of social security system of that contracting State (so either Czech Republic or Slovakia) in which the relevant insurance periods were completed and subject to the responsibility of this States social security authorities. Thus a person of Czech nationality, who acquired the pension entitlement in Czech Republic, but a part of his/hers insurance periods were completed in the Slovak territory before the dissolution date, had the respective part of the benefit calculated under the Slovak system rules and paid by Slovak institution. That was the case of Ms. M. Landtová. However, in 2005 the Czech Constitutional Court (Ústavni soud) issued a judgment on interpretation of Art. 20(1) of the abovementioned Agreement. Accordingly, where a Czech national (residing also in Czech Republic) satisfies the conditions for entitlement to a pension and the amount of it as set by Czech law is greater than that laid down by the social security Agreement, the Czech Social Security Authority (CSSA) must ensure that the retirement pension is of an amount equivalent to the higher entitlement (set by Czech legislation). Therefore, the CSSA supplements the retirement pension paid by the other contracting State, which must be taken into account in order to avoid double payment of two retirement pensions of the same kind, granted on the same grounds by two separate social security institutions. ${ }^{53}$

Ms. Landtová in 2006 was awarded a partial retirement pension by the CSSA, however her benefit was calculated solely on the basis of the Slovak scheme. She challenged the decision before the Metropolitan Court in Prague (Městsky soud v Praze). The Court annulled the CSSA's decision in accordance with the 2005 Constitutional Court judgment and concluded that the benefit paid

50 Case C-399/09 Marie Landtová v Česká správa socialního zabezpečení (CJEU, 22 June 2011).

51 The case before Czech courts known as Slovak Pension Rights, see to that respect A. Dyevre (n. 10) and the texts by Wyrozumska and Skomerska-Muchowska in the present volume.

52 "[P]eriods of insurance completed before the date of dissolution of the Czech and Slovak Federal Republic shall be considered to be periods of insurance completed in the contracting State on whose territory the employer of the person concerned had its headquarters either on the day of the dissolution, or on the last day before that date"; Case C-399/09 Landtová, paras 8-9.

53 Case III. ÚS 252/04 (Czech Constitutional Court, 25 January 2005). 
to Ms. Landtová by the CSSA should be adjusted up to the amount that would be due under the Czech social security scheme. The CSSA brought an appeal on a point of law before the Supreme Administrative Court (Nejvyšši správní soud). The latter set aside the judgment of the Metropolitan Court and referred the case back for reconsideration, questioning i.a. whether the 2005 Constitutional Court judgment and the preferential treatment granted thereby to nationals of the Czech Republic were compatible with the principle of equal treatment laid down in Article 3(1) of Regulation 1408/71. ${ }^{54}$ Nevertheless, the Metropolitan Court upheld its position and ruled that the CSSA was required to supplement the benefit. Subsequently the CSSA brought another appeal to the Supreme Administrative Court, claiming that the obligation to adjust the benefits solely for individuals of Czech nationality residing in the territory of the Czech Republic under the conditions set out in the 2005 judgment, was contrary to Art. 3 of the Regulation 1408/71 (principle of equal treatment) and since, such an obligation also involved taking into account Slovak periods of insurance, it was also contrary to Art. 12 (stating that the same period of insurance cannot be taken into account twice). The Supreme Administrative Court shared the CSSA doubts and submitted a reference for a preliminary ruling to the CJEU. ${ }^{55}$

The Court of Justice admitted that the provisions of Regulation 1408/71 did not preclude a national rule, which provided for payment of a supplement to pension benefit in the circumstances established under the 2005 Constitutional Court judgment. ${ }^{56}$ Nevertheless, with regard to the principle of equal treatment, the CJEU was not convinced by the arguments of uniqueness and specialty of the national regulation, which had been adopted to deal with the effects of an exceptional situation of dissolution of a State and creation of two new States. It ruled that provisions of Regulation 1408/71 did preclude a national rule, which allowed payment of a supplement to old age benefit solely to Czech nationals residing in the territory of the Czech Republic. At least, the CJEU stressed that it did not necessarily follow from such statement that, under EU law, a person who satisfied the two requirements of nationality and residence should be deprived of such a payment. The idea behind the CJEU ruling was, therefore, not to restrict the supplement system but to enable also individuals other than Czech nationals resident in Czech Republic, and fulfilling other criteria, to benefit from it. One may wonder whether this was the judgment the CSSA and the referring court might have hoped for. Despite that, the CJEU was heavily criticized for this ruling and the critique cannot be called as wholly

54 Regulation (EEC) No. 1408/71 of the Council of 14 June 1971 on the application of social security schemes to employed persons and their families moving within the Community, O.J. L 1491971 2, with subsequent amendments. 
undeserved. ${ }^{57}$ In our view, Landtová makes a perfect example of a case where both courts lost a great opportunity to remain silent. The right way to act was shown twice by the court of first instance in the domestic proceedings - the Metropolitan Court, which though induced by the first appeal judgment of the Supreme Administrative Court, used its freedom and did not regard the explanation of EU law issues necessary to enable it to decide the case. It is hard to resist the impression that the driving force that led the Supreme Administrative Court to file the request for a preliminary ruling was the rivalry with the Constitutional Court and the desire to have the latter's judgment reversed by using the preliminary ruling of the CJEU. The CJEU could have avoided the dialogue as well, by declaring the questions irrelevant for the domestic proceedings. The national regulation in question was a recognized exception to the EU social security coordination system, it was justified by unique situation of dissolution of a State long before the EU accession of its successors and, last but not least, it concerned a really limited group of individuals, which would diminish year by year until they would simply die out. One must really ask what reason, other than vanity, made the CJEU entertain this case, bearing in mind that before and afterwards it gave rise to such a controversy among the judiciary and scholars, crowned by the unprecedented declaration of the CJEU judgment as ultra vires by the Czech Constitutional Court in 2012..$^{8}$ This case constitutes a remarkable (and a surprising) example that judicial dialogue may be driven by emotions. Then the dialogue does not bring any good. One may only hope that the CJEU and the national courts would draw right conclusions from this example to avoid similar situations in the future.

\subsection{Hungary}

Of the four EU Member States studied in our research Hungary is the one with by far the largest number of preliminary references submitted, both in terms of absolute numbers and in relation to the country's size and population..$^{59}$ Within the research period there were ninety-four cases submitted and closed. Eight of them were removed from the register due to withdrawal. In eleven instances, the CJEU declared its lack of jurisdiction. Among these eleven, in one particularly important Ynos case the declaration was made by means of a judgment instead of an order. ${ }^{60}$ As to the referring courts, there is no leading category of courts that comes to a forefront. We may point to around fourteen references that came from the Hungarian Supreme Court (present Kúria, previously Legfelsőbb Bíróság).

57 See in that respect the texts by Wyrozumska and Skomerska-Muchowska in the present volume.

58 Case ÚS 5/12 Slovak Pensions XVII (Czech Constitutional Court, 31 January 2012).

59 M. Broberg, N. Fergen (n. 10) 34.

60 Case C-302/04 Ynos kft v János Varga (CJEU, 10 January 2006) - see further reference to this case in the present paper. 
The rest was sent by courts of all levels, of general and specialized jurisdictions, adjudicating in all instances.

Accordingly, the subject matter of Hungarian references is much diversified and it is hard to indicate one or two prevailing domains. Taking a very generalizing approach one may state that the majority of references regarded various aspects of the four internal market freedoms. There was also a considerable number of taxation cases (seventeen) as well as questions within the field of competition and consumer protection (seventeen too). Some references regarded common agricultural policy (seven). What is though especially noteworthy, there were five cases concerning the area of freedom security and justice. The remaining instances concerned e.g. jurisdiction of national courts and judicial cooperation, environment or protection of personal data.

The Ynos case was the first preliminary reference submitted by a Hungarian court. As already suggested, it regarded such an interesting and significant problem - from the perspective of application of EU law in the Member States, which joined in 2004 - that the CJEU despite finding the lack of jurisdiction decided over it by means of a judgement and not by an order which would be typical in such situation. The details of the proceedings before the referring court are not relevant for the outcome of preliminary ruling. It is sufficient to state that it concerned the effects of unfair terms used in consumer contracts, which had been concluded and in respect of which a dispute had arisen before Hungary's accession to the EU. However, the provisions of Hungarian law regarding unfair contract terms had already been adapted to the EU Directive 93/13 when this situation occurred. ${ }^{61}$ The national court for that reason assumed that the interpretation and application of these domestic rules had to be in conformity with the Directive. ${ }^{62}$ Though the national court seemed quite convinced about this assumption, it included within the reference, as last, a question on this particular issue. ${ }^{63}$ The CJEU, however, took an entirely opposite view and stated that it had jurisdiction to interpret the Directive only as regards its application in a new Member State with effect from the date of that State's accession to the EU and since the facts of the case before the referring court occurred prior to the Hungary's accession to the EU, the Court did not have jurisdiction to interpret the Directive. ${ }^{64}$ Consequently, before the accession to the EU of a new Member State, no obligation could be established for the national court to interpret the domestic law in conformity with the wording and purpose of the Directive. Therefore, the judicial dialogue in this case contributed to the clarification of the scope of the obligation of EU conform interpretation (the indirect effect of directives/EU law).

61 Council Directive 93/13/EEC of 5 April 1993 on unfair terms in consumer contracts O.J. L 95 199329.

62 Case C-302/04 Ynos, para. 28.

63 It was preceded by two questions on the interpretation of the directive's provisions; ibidem, para. 29.

64 Ibidem, 37. 
The Cartesio preliminary ruling was already referred to in the context of dialogue-generating features. ${ }^{65}$ Now we shall deal with the substantial problems of the case, which regard freedom of establishment. Cartesio, the applicant in the main proceedings, was a company established under Hungarian law with a seat in Baja (Hungary). In November 2005 the company applied to the competent national court for registration of the transfer of its seat to Gallarate in Italy and for subsequent amendment of the information on its seat in the commercial register. The company, however, was to remain governed by Hungarian law. The application was rejected on the ground that the Hungarian law in force did not allow a company established in Hungary to transfer just its seat abroad while continuing to be subject to Hungarian law. ${ }^{66}$ According to the registry court a transfer like that would require that the company ceases to exist under Hungarian law and, then, it re-establishes itself in compliance with the law of the country of its new seat. Cartesio appealed against that decision to the Provincial Court of Appeal in Szeged (Szegedi İtélötábla). The appellate court examined the up-to-date CJEU jurisprudence on freedom of establishment. It concluded that, so far, Arts. 49 and $54 \mathrm{TFEU}^{67}$ did not include the right for a company established under the legislation of one Member State to transfer its central administration (and thus its principal place of business) to another Member State whilst retaining its legal personality and nationality of origin. Yet, if the competent authorities where to object to such rule, the content of Arts. 49 and 54 TFUE may be further refined in the future case law of the CJEU. ${ }^{68}$ The appellate court subsequently referred to some judgements, which could serve as a starting point for such potential development. ${ }^{69}$ Therefore the court decided to refer the questions concerning this problem and also some aspects of interpretation of Art. 267 TFEU to the CJEU.

The Court of Justice stated that, in the absence of EU legislation, the Member States are competent to determine the requirements under which a company was to be regarded as established under their respective legislations and, accordingly, capable of enjoying the right of establishment, and the requirements, under which it was able subsequently to maintain that status. Thus the CJEU held that the freedom of establishment did not preclude one Member State from preventing a company established under its national law from transferring its seat to another Member State whilst retaining its status as a company governed by the law of the first Member State. ${ }^{70}$ On the other hand, where a company established under the law of one Member State moves to another Member State it not only changes the seat, but also is converted into a form

\footnotetext{
65 See above, para. II.

66 Case C-210/06 Cartesio, paras 23-24.

67 Former Arts. 43 and 48 TEC.

68 Case C-210/06 Cartesio, paras 34-35.

69 Ibidem, paras 36-39.

70 Ibidem, paras 109-110.
} 
of company governed by the law of the latter. In a situation like that the freedom of establishment permits a company to convert without having to be wound up or to enter into liquidation in the Member State of original establishment, to the extent the law of the host Member State allows for such a conversion, unless a restriction of the freedom of establishment serves overriding requirements of the public interest. ${ }^{71}$

These principles were complemented by developments delivered in the VALE Épitési preliminary ruling. ${ }^{72}$ An Italian company VALE COSTRUZIONI was established and registered in Rome in 2000. In February 2006, the company applied to be deleted from that register as it wished to discontinue business in Italy in order to transfer its seat and business to Hungary. Subsequently it was removed from the Italian commercial register with a notice "the company had moved to Hungary." Instantly afterwards a company VALE Építési Kft. was incorporated and its representative requested a competent Hungarian court to register the company in Hungary with an entry stating that VALE COSTRUZIONI was the predecessor in law of VALE Építési Kft. However, that application was rejected by the Hungarian registry court (Fövárosi Bíróság) on the ground that a company incorporated and registered in another State could not transfer its seat to Hungary and could not be registered there as the predecessor in law of a Hungarian company. Hungarian law allowed only for Hungarian companies to convert, but did not permit a company governed by the law of another Member State to convert to a Hungarian company. ${ }^{73}$ VALE Építési appealed against the decision but the appeal was rejected by the Provincial Court of Appeal in Budapest (Fövárosi Itélőtábla). The company then lodged another appeal to the Supreme Court (Legfelsöbb Bíróság). The Supreme Court shared the applicant's serious doubts as to the compatibility of Hungarian provisions in respect of company conversion with the EU law, in particular freedom of establishment, and submitted the preliminary reference to the CJEU on that matter.

The CJEU started its reasoning with an assertion that in the absence of a uniform regulation of companies in EU law, it was for the national legislation to determine the conditions of their incorporation and functioning. Therefore, the host Member State may determine the national law applicable to cross-border company conversions and apply its domestic provisions on the conversion of its national companies. ${ }^{74}$ However, the Court argued that under the Hungarian law companies were treated in general manner differently according to whether the conversion was domestic or of a cross-border nature, since only the former was provided for in Hungarian legislation. Such discriminatory treatment is very likely to deter companies, which have their seat in other Member States from exercising the freedom of establishment and amounts to an unjustified restriction

71 Ibidem, para. 111.

72 Case C-378/10 - VALE Építési Kft. (CJEU, 12 July 2012).

73 Ibidem, 9-11.

74 Ibidem, paras 28-29. 
on the exercise of that freedom. ${ }^{75}$ Thus the CJEU concluded that Arts. 49 and 54 TFEU had to be interpreted as precluding legislation of a Member State which enabled companies established under its national law to convert, but did not allow, in a general manner, companies governed by the law of another Member State to convert to companies governed by law of the former Member State. ${ }^{76}$ In respect of the application of existing national provision to the cross-border conversions, the CJEU pointed that they needed to be applied in compliance with the principles of equivalence and effectiveness, to ensure the protection of the rights which individuals acquire under EU law. Therefore, the application of Hungarian provisions on domestic conversions governing the establishment and functioning of companies, such as the requirements to draw up lists of assets and liabilities and property inventories, cannot not be questioned. ${ }^{77}$ Analogically, where a Member State requires, in the context of a domestic conversion, a strict legal and economic continuity between the predecessor company and the converted successor company, such a requirement may also be imposed in the context of a cross-border conversion. ${ }^{78}$ The CJEU stressed, however, that EU law precluded the Member State from refusing to record in its register, in the case of cross-border conversions, the original company (of another Member State) as the predecessor in law of the converted company, if such a record was made in respect of domestic conversions. ${ }^{79}$

The examples of Cartesio and VALE Épitési demonstrate that the dialogue within the preliminary reference procedure may lead to elaboration of quite detailed rules regulating in a comprehensive way of a legal issue in the absence of common EU legislation thereon - in this case regarding the cross-border company conversions in the context of the freedom of establishment.

Among the preliminary references submitted by Hungarian courts there is a relatively small but topically important share of cases concerning the area of freedom, security and justice, with particular regard to rights of third country nationals. ${ }^{80}$ The one concerning probably the most unusual problem is Shomodi. In this case, the Hungarian Supreme Court (Legfelsöbb Bíróság) sought the CJEU's interpretation of provisions of EU Regulation 1931/2006 on local border traffic in relation to the Convention implementing Schengen

\footnotetext{
Ibidem, para. 34.

Ibidem, para. 41.

Ibidem, para. 52.

Ibidem, para. 55.

Ibidem, para. 56.

80 See CJEU cases: C-404/07 György Katz v István Roland Sós (9 October 2008); C-31/09 Nawras Bolbol v Bevándorlási és Állampolgársági Hivatal (17 June 2010); C-254/11 Szabolcs-Szatmár-Bereg Megyei Rendőrkapitányság Záhony Határrendészeti Kirendeltsége v Oskar Shomodi (21 March 2013); C-364/11 Mostafa Abed El Karem El Kott and Others v Bevándorlási és Állampolgársági Hivatal (19 December 2012).
} 
Agreement. ${ }^{81}$ Under that Convention, foreign nationals not subject to a visa requirement may move freely within the Schengen area for a maximum period of three months during the six months following the date of first entry. ${ }^{82}$ The Regulation 1931/2006 contains specific provisions that apply to third country nationals who are residents in a border area of a non-Member State, which borders a Member State of the EU (an area that extends no more than 30 kilometres from the border). The 'border residents' may obtain a local border traffic permit, which enables them to enter the neighbouring Member State and remain there for an uninterrupted period. The duration of this period is determined by agreements concluded between the neighbouring States (on the basis of the Regulation 1931/2006) but may not exceed three months and such permits do not authorise their holders to move beyond the border area of the Member State visited. ${ }^{83}$ The agreement on the local border traffic between Hungary and Ukraine determines the maximum duration of a stay in Hungary for Ukrainian border residents as three months of uninterrupted stay. ${ }^{84} \mathrm{Mr}$. O. Shomodi, a Ukrainian national is a holder of a local border traffic permit and accordingly is authorised to enter the border area of Hungary. On 2 February 2010 he requested entry into Hungary at the Záhony border crossing, however the Hungarian border police found that he had stayed in Hungarian territory for 105 days during the period from 3 September 2009 to 2 February 2010, having entered that territory almost daily for several hours. Since he had thus exceeded, in the view of the Hungarian border police, the time limit of three months, the police denied him entry onto Hungarian territory. ${ }^{85}$

Mr. Shomodi brought an action against the decision of the border police to the Provincial Court (Szabolcs-Szatmár-Bereg megyei biróság), which ruled that general regulations of EU and Hungarian law on cross-border traffic were not applicable. The court applied the special rules on local border traffic and found there was no limit on the number of entries to which the holder of a local border traffic permit was entitled and that the three-month limit applied only to uninterrupted stays. Therefore, the court concluded that the grounds relied on by the border police did not justify the refusal to Mr. Shomodi to enter Hungarian territory and reversed the decision. ${ }^{86}$ The border police appealed against this judgement to

81 Regulation (EC) 1931/2006 of the European Parliament and of the Council of 20 December 2006 laying down rules on local border traffic at the external land borders of the Member States and amending the provisions of the Schengen Convention, O.J. L 4052006 1, corrigendum O.J. L 292007 3; Convention implementing the Schengen Agreement of 14 June 1985 between the Governments of the States of the Benelux Economic Union, the Federal Republic of Germany and the French Republic on the gradual abolition of checks at their common borders, signed at Schengen on 19 June 1990, O.J. L 239200019. 
the Supreme Court (Legfelsöbb Bírósága), which referred to the CJEU questions on the interpretation of specific border traffic rules, in particular the character and way of counting of the time limits. ${ }^{87}$

In its preliminary ruling the CJEU stated that the general rules of the Schengen acquis did not apply to local border traffic and pointed out that the three month limit laid down by the local border traffic regulation related only to 'uninterrupted stays', whereas the limitation resulting from the general rules of Schengen acquis did not contain that reservation. ${ }^{88}$ Moreover, by adopting the regulation on local border traffic, the EU legislature intended to put rules in place for local border traffic, which are distinct from the general rules of Schengen acquis and are subject to autonomous interpretation. The purpose of those rules, namely, is to enable the residents of the border areas to cross the external land borders of the EU for legitimate economic, social, cultural or family reasons, and to do so easily (understood as without excessive administrative constraints) and frequently, even regularly. ${ }^{89}$ However, as the CJEU noted that facilitation of border crossing was intended for bona fide ('good will') border residents with legitimate reasons for frequently crossing the border, so the Member States remained free to impose penalties on those who abuse or fraudulently used their local border traffic permits. ${ }^{90}$ Accordingly, the CJEU concluded that the holder of a local border traffic permit needed to be able to move freely within the border area for a period of three months if his stay was uninterrupted and to have a new right to a three-month stay each time that his stay was interrupted. Consequently, in the view of the CJEU, the stay must be regarded as interrupted as soon as the person concerned crosses the border back into his State of residence in accordance with the conditions laid down in the local border traffic permit, irrespective of the frequency of such crossings, even if they occur several times daily. ${ }^{91}$

Shomodi constitutes thus an example of affirmative judicial dialogue, where the CJEU entirely confirmed the argumentation and the propriety of the judgment of the court of first instance. It also strengthens the effectiveness of individual rights - and does so in relation to a particular group of third country nationals, who turn out to be beneficiaries of judicial dialogue as well.

\subsection{Lithuania}

Within the period covered by our research the Lithuanian courts submitted twenty-seven references, of which none had been withdrawn and, remarkably none had been declared inadmissible. The total number is relatively not that small

\footnotetext{
87 Ibidem, para. 18.

88 Ibidem, para. 23.

89 Ibidem, para. 24.

90 Ibidem, para. 25.

91 Ibidem, paras 26, 28-29.
} 
(although still below Union average), taking into account the size and population of the country. ${ }^{92}$ Remarkably, the Lithuanian references concern such a variety of EU law issues that it is harder than in case of the three remaining States under scrutiny, to organise them on the basis of their subject matter. It seems that there are no prevailing themes in the preliminary reference practice of Lithuanian courts. In fact, very often one case addressed a number of issues, including also systemic problems of EU legal order. It is also worth noticing, in comparison with the three remaining Member States that the vast majority of references comes from the highest judicial authorities of Lithuania, the Lietuvos Aukščiausiasis Teismas (the Supreme Court) and the Lietuvos vyriausiasis administracinis teismas (the Higher Administrative Court). Moreover, importantly, the Constitutional Court (Lietuvos Respublikos Konstitucinis Teismas) was one of the first Lithuanian courts to submit a preliminary reference to the CJEU.93

One of the most interesting Lithuanian cases in terms of the use of judicial dialogue for strengthening of the protection of individual rights is the case $\mathrm{Pe}$ ftiev. ${ }^{94}$ The case constituted a smart challenge to EU smart sanctions adopted against Belarus. ${ }^{95}$ Mr. Peftiev and other respondents in the main proceedings were included in the list of persons subject to EU measures against Belarus. In order to challenge those measures, they hired a Lithuanian law firm, which brought actions for annulment before the EU General Court. Subsequently, the law firm issued four invoices for its legal services to the respondents and the clients transferred the corresponding sum to the law firm's bank account. However, due to the effect of EU sanctions in force, the transferred funds were frozen in the law firm's bank account. In turn, the respondents in the main proceedings, according to the provisions of the sanctions regulation made a request to the Lithuanian authorities for lifting the measures freezing the financial funds in so far, as it was necessary to pay for the legal services. The request was refused, as the funds were allegedly acquired unlawfully. Mr. Peftiev and others brought then actions for annulment of those decisions before the Regional Administrative Court in Vilnius asking it to annul the decisions and to order their reconsideration by the administrative organs, which issued them. The court actually decided in favour of the respondents in the main proceedings, but on this occasion the administrative authorities appealed against the judgment to the Lithuanian Supreme Administrative Court (Lietuvos vyriausiasis administracinis teismas), rising the argument that they enjoyed on the basis of the Sanctions Regulation absolute discretion in deciding whether or not to apply the derogation, because decisions in that respect were linked to political issues

92 M. Broberg, N. Fergen (n. 10), p. 34.

93 Case C-239/07 Julius Sabatauskas and Others (CJEU, 9 October 2008).

94 C-314/13 Užsienio reikalų ministerija and Finansinių nusikaltimu tyrimo tarnyba $v$ Vladimir Peftiev and Others (CJEU, 12 June 2014).

95 Council Regulation (EC) 765/2006 of 18 May 2006 concerning restrictive measures in respect of Belarus O.J. L 1342006 1, with subsequent amendments. 
and external relations of Member States have with other States, which is an area in which they should have a broader freedom of action. However, the Supreme Administrative Court considered the problem in connection with the Council document "EU Best Practices for the effective implementation of restrictive measures" 96 and the CJEU case law and came to the conclusion that interpretation of that kind of provision must take into account the need to ensure protection of fundamental rights, including the right to a judicial remedy. The only way for a person affected by a restrictive measure to have this measure annulled is to bring an action before the EU Court. But in order to do that, the applicant is required to have legal representation (under the Rules of Procedure of the General Court); the GC itself, as the Supreme Administrative Court observed, in cases of this character exhaustively examined the requests to grant the legal aid and, where necessary, granted it. ${ }^{97}$ On the basis of this analysis, the court referred to the CJEU questions concerning, on one hand, the alleged absolute discretion of administrative organs while deciding on granting of derogation. On the other hand, the referring court, in case the scope of discretion turned out to be not that absolute, asked about the criteria and circumstances which must be regarded when the grant of derogation is decided upon (including the effectiveness of protection of individual's fundamental rights as well as safeguards against misuses of derogation) and whether the (allegedly unlawful) source of the funds had any relevance for the decision on derogation. ${ }^{98}$ The CJEU entirely supported the observations of the referring court. It started by reminding national authorities that when deciding on a request for release of frozen funds pursuant to Regulation 765/2006, they implemented EU law, and accordingly, they were required to observe the Charter of Fundamental Rights of the European Union ('the Charter'). ${ }^{99}$ In consequence, the provisions of the Regulation must be interpreted as meaning that, when taking a decision on granting a derogation requested with an aim to enable an individual to challenge the lawfulness of restrictive measures imposed by the $\mathrm{EU}$, the competent national authority does not enjoy absolute discretion, but must exercise its powers in a manner which upholds the rights provided for in Art. 47 (right to effective legal remedy and access to court) of the Charter and observes the indispensable nature of legal representation in bringing such an action before the General Court. ${ }^{100}$ As to provision of safeguards against the misuse of the derogation granted, the CJEU emphasized, that national authorities may verify whether the requested release of funds was intended exclusively for payment of reasonable professional fees

96 Council document 11679/07 EU of 9 July 2007 "Best Practices for the effective implementation of restrictive measures", http://register.consilium.europa.eu/doc/srv?l=EN\&f=ST\%20 11679\%202007\%20INIT (access: 5 April 2017).

97 Case C-314/13 Peftiev, paras 20-21.

98 Ibidem, para. 22.

99 Ibidem, para. 24.

100 Ibidem, para. 34. 
and reimbursement of incurred expenses associated with the provision of legal services and they may also set the appropriate conditions in order to guarantee, inter alia, that the objective of the sanction is not frustrated and the derogation granted is not distorted. ${ }^{101}$ Finally, as the applicable provisions of Regulation $765 / 2006$ make no reference to the origin of the funds in question or possible unlawful acquisition thereof, such circumstances are not relevant for granting a derogation from freezing those funds in order to pay for legal services. ${ }^{102}$ The Peftiev ruling constitutes then a great example of judicial dialogue strengthening the protection of fundamental rights and the position of individual by application of the Charter of Fundamental Rights even in respect of measures taken the field of external policy of the EU.

Another very interesting instance of development of EU law by means of preliminary ruling procedure is the Gazprom judgment. ${ }^{103}$ The case concerned a competence dispute between a Lithuanian court and an arbitral tribunal in respect of proceedings, which involved a company Lietuvos dujos in which the Lithuanian State had share. The remaining shareholders were Gazprom and the German Company E.ON Ruhrgas. In 2004 the shareholders concluded an agreement, which contained in Section 7.14, an arbitration clause according to which "[a]ny claim, dispute or contravention in connection with this Agreement or its breach, validity, effect or termination, shall be finally settled by arbitration." In 2011 Lithuania (represented by the Ministry of Energy) requested that the Provincial Court in Vilnius investigates activities of the company (in connection with actions of the management board which the ministry found improper) on the basis of the Lithuanian civil code. In return, Gazprom instituted arbitral proceedings claiming that bringing the action to Lithuanian court infringed the arbitral clause of the shareholders agreement. In July 2012, the arbitral tribunal declared that the arbitration clause had been partially breached and ordered Lithuania, in particular, to withdraw or limit some of its claims brought before the Provincial Court. Meanwhile, in September 2012, the Provincial Court ordered the investigation of the activities of Lietuvos dujos company and declared also held that an application for investigation of the activities of a legal person fell within its jurisdiction and was not subject to arbitration under Lithuanian law. The company and the members of its management board appealed against that decision to the Court of Appeal of Lithuania. In separate proceedings, Gazprom applied to that court for recognition and enforcement in Lithuania of the arbitral award of July 2012. The Court of Appeal dismissed Gazprom's application, recalling the provisions of Lithuanian law and the Convention on the Recognition and Enforcement of Foreign Arbitral Awards, signed in New York on 10 June $1958 .{ }^{104}$ The court observed that, by the arbitral award

\footnotetext{
101 Ibidem.

102 Ibidem, para. 40.

103 Case C-536/13 Gazprom OAO v Lietuvos Respublika (CJEU, 13 May 2015).

104 United Nations Treaty Series, Vol. 330, p. 3.
} 
of July 2012 recognition and enforcement of which were sought, the arbitral tribunal limited the ministry's capacity to bring proceedings before a Lithuanian court for initiation of an investigation in respect of the activities of a legal person, but also denied that national court the power to determine whether it has jurisdiction at all. By doing so the arbitral tribunal infringed the sovereignty of the Republic of Lithuania, which as contrary to Lithuanian and international public policy, justified the refusal to recognize the arbitral award. ${ }^{105}$ By a separate order the court also dismissed the company's appeal and confirmed the jurisdiction of the Lithuanian courts to hear that case. ${ }^{106}$ Both orders were subject of an appeal to the Lithuanian Supreme Court. That Court decided to deal with the appeal concerning recognition and enforcement of the arbitral award and to suspend the second appeal until the first had been decided. Since the Supreme Court was uncertain, upon taking into account the relevant case law of the CJEU and provisions of Regulation 44/2001, ${ }^{107}$ whether the recognition and enforcement of the arbitral award could be refused on the grounds given by the Court of Appeal. ${ }^{108}$ Therefore, the Supreme Court referred to the CJEU some questions on the interpretation of the regulation. In its reply, the CJEU observed that actually the problem of recognition of arbitral awards was expressly excluded from the scope of Regulation 44/2001. ${ }^{109}$ However, instead of declaring the lack of jurisdiction in the referred case, the CJEU went on and gave the referring court exhaustive guidance on how the courts should interpret their own competence-competence and the breadth of the margin of discretion they enjoy while determining whether they have jurisdiction over a given case or not. It is striking, how the Court of Justice formulated the conclusion of the judgment, thus linking it with interpretation of provisions, which are not applicable to the case at all:

Council Regulation (EC) No. 44/2001 of 22 December 2000 on jurisdiction and the recognition and enforcement of judgments in civil and commercial matters must be interpreted as not precluding a court of a Member State from recognising and enforcing, or from refusing to recognise and enforce, an arbitral award prohibiting a party from bringing certain claims before a court of that Member State, since that regulation does not govern the recognition and enforcement of an arbitral award issued by an arbitral tribunal in another Member State.

However, if we take into account the role of courts as guardians of the rule of law and the growing controversies concerning arbitration as means of resolution of commercial disputes involving also States (e.g. within the recently agreed

105 Case C-536/13 Gazprom, para. 22.

106 Ibidem, para. 23.

107 Council Regulation (EC) 44/2001 of 22 December 2000 on jurisdiction and the recognition and enforcement of judgments in civil and commercial matters O.J. L 1220011.

108 Case C-536/13 Gazprom, para. 25.

109 Ibidem, paras 28, 40-41. 
upon CETA), we do not tend to be too critical about the CJEU's position in the present case. In addition, the Gazprom ruling demonstrates one more function of judicial dialogue: that of education of judges and of the general public.

\subsection{Poland}

Although Poland with sixty-five cases takes a second place (after Hungary) in terms of absolute numbers, the statistics are less impressive when it comes to classification related to size and population of the country. ${ }^{110}$ In two cases the references were withdrawn. In six of the remaining cases the CJEU declared itself incompetent to adjudicate on the matters, however, as noticed earlier, the inadmissible references are not always irrelevant for development of EU law. Nearly two thirds of the Polish references came from the administrative courts (the provincial administrative courts and the Supreme Administrative Court Naczelny Sad Administracyjny). On the other end lies the Polish Supreme Court (Sad Najwyższy), which had only submitted six references. The remainder of cases originated from district and provincial courts. In respect of subject matter of the rulings, there is an overwhelming domination of tax law cases. Apart from them there are few concerning competition, consumer protection, problems of jurisdiction, pensions and a number of single other issues. Many of the cases, especially tax cases, concern very particular, sometimes technical issues relevant only for the case referred. However, there are still numerous ones addressing fundamental, systemic problems of EU law.

One of such issues was considered in the Filipiak case, ${ }^{111}$ which revealed problems that might occur within the 'border zone' between the domestic constitutionality review procedure and the application of EU law. The main proceedings before the national court (the Provincial Administrative Court in Poznań, Wojewódzki Sąd Administracyjny w Poznaniu) concerned the Polish income tax legislation which allowed for deductions of contributions paid for social security and health insurance in the calculation of the amount of income tax obligation under the condition that these contributions belonged to categories specified in Polish legislation. In the effect, the only contributions to be deduced were those paid to the institutions of Polish social security and health insurance systems. Mr. Filipiak, as a partner of a Dutch partnership, paid in the Netherlands the social security and health insurance contributions required of him by Dutch legislation, however paid his income tax in Poland. He claimed that such regulation of Polish income tax law was incompatible with EU law, in particular the internal market freedoms. Accordingly, the contested provisions could not be applied by virtue of the principles of direct effect and primacy of EU law.

110 M. Broberg, N. Fergen, Preliminary References..., p. 34.

111 Case C-314/08 Krzysztof Filipiak v Dyrektor Izby Skarbowej w Poznaniu (CJEU, judgment, 19 November 2009). 
Unfortunately, the Polish tax authorities did not agree with him and in consequence, Mr. Filipiak brought an action against their decisions to the Provincial Administrative Court in Poznań.

The Court shared the applicant's concerns as to the conformity of Polish legislation with EU law and decided to submit a preliminary reference to the CJEU. It observed, however, that it was essential to examine whether the contested Polish provisions were compatible with a Treaty provision, which was not relied on by the applicant, ${ }^{112}$ namely the current Art. 49 TFEU (former Art. 43 TEC) providing for the freedom of establishment. The Court also argued that the effect of the contested provisions was that a taxpayer, being subject to unlimited tax liability in Poland on the entirety of his income and pursuing an economic activity in another Member State was not allowed to deduct in the calculation of his tax obligation the contributions for social security and health insurance paid in the Netherlands also paid in the Netherlands, even though those contributions were not deducted in that Member State. ${ }^{113}$ Furthermore, the referring court drew attention to the fact that the Polish Constitutional Court (Trybunat Konstytucyjny) had already ruled on the compatibility of the contested provisions of the law on income tax with the Polish Constitution, holding that

to the extent to which the tax provisions at issue do not allow taxpayers specified in Article 27(9) of the Law on income tax to deduct social security and health insurance contributions from income deriving from an activity pursued outside the Republic of Poland and from the tax payable thereon where those contributions were not deducted in the Member State in which that activity was pursued, those provisions are not compatible with the principle of equality before the law laid down in Article 32 of the Polish Constitution, in conjunction with the principle of social justice, set out in Article 2 of that Constitution. ${ }^{114}$

The Constitutional Court, though, decided (pursuant to Art. 190(3) of the Polish Constitution) to defer the date when the provisions declared unconstitutional would lose all binding force to 30 November $2008 .{ }^{115}$ Therefore, the questions referred to the CJEU by the Provincial Administrative Court regarded on one hand, whether Art. 49 TFEU should be interpreted as precluding the provisions such as the ones in the contested Income tax law. On the other hand, the referring court wondered whether the principle of the primacy of EU law should be interpreted as taking precedence over the provisions of national law in so far as the entry into force of the judgment of the Polish Constitutional Court had been deferred on the basis of those provisions. ${ }^{116}$

112 Mr. Filipiak indicated Art. 45 TFEU (former Art. 39 TEC, free movement of workers).

113 Case C-314/08 Filipiak, para. 22.

114 Ibidem, paras 23-24. See: Case K 18/06 (Polish Constitutional Court, 7 November 2007).

115 Case C-314/08 Filipiak, para. 25. The maximum deference period provided for in that provision is 18 months.

116 Ibidem, para. 26. 
While responding to the first question of the Polish court, the CJEU observed that the refusal to grant to a taxpayer the right to deduction of compulsory contributions paid in another Member State in circumstances like those in the main proceedings might deter individuals from taking advantage of the freedom of establishment and freedom to provide services and amounted to a restriction on those freedoms. Such restriction could only be justified by overriding reasons in the public interest. ${ }^{117}$ Thus, the CJEU concluded that EU law precluded the national legislation like that contested in the proceedings before the referring court. ${ }^{118}$ With regard to the second question the CJEU argued that according to the principle of the primacy of EU law, a conflict between a provision of national law and a directly applicable provision of the Treaty needed to be resolved by application of EU law by a national court, and if necessary by refusing the application of a conflicting national provision, and not by its annulment. Subsequently, the Constitutional Court's deferral of the date on which the provisions, which it declared unconstitutional, would lose their binding force did not preclude the national courts from respecting the principle of the primacy of EU law and from declining to apply those provisions as contrary to EU law. In the effect, the primacy of EU law obliges the national court to apply EU law and to refuse to apply the conflicting provisions of national law, irrespective of the judgment of the national constitutional court deferring the date on which those provisions, would stop to be in force in a national legal order. ${ }^{119}$ In this way, the dialogue between the CJEU and the Polish administrative Court clarified the relationship between the primacy of EU law and the effect of rulings of Member States' constitutional courts.

Another preliminary ruling originating from a Polish court, which contributed to the development of EU law was Polska Telefonia Cyfrowa. ${ }^{120}$ Polska Telefonia Cyfrowa sp. z o.o. (PTC) was one of the main telecommunications operators in Poland. In 2006, the President of the Office for Electronic Communications (Prezes Urzędu Komunikacji Elektronicznej, President of UKE) identified PTC as having significant market power in the market for the provision of voice call termination services. By means of an administrative decision the President of UKE imposed on PTC certain regulatory requirements. It is necessary to mention that under the Directive 2002/21 $1^{121}$ the Commission is empowered to publish

\footnotetext{
117 Ibidem, paras 71-72.

118 Ibidem, para. 73.

119 Ibidem, paras 82-84.

120 Case C-410/09 Polska Telefonia Cyfrowa sp. z o.o. v Prezes Urzędu Komunikacji Elektronicznej (CJEU, 12 May 2011).

121 Directive (EC) 2002/21 of the European Parliament and of the Council of 7 March 2002 on a common regulatory framework for electronic communications networks and services ('Framework Directive'), O.J. L 108200233.
} 
guidelines ${ }^{122}$ concerning market analysis and the assessment of significant market power. The national regulatory authorities (NRAs - in Poland the President of the UKE) are obliged by the provisions of the Directive to take the said guidelines into account for the definition of relevant markets appropriate to national circumstances and, in particular, of relevant geographic markets within their territory, in accordance with the principles of competition law. ${ }^{123}$ The PTC contested the decision before Polish courts, claiming that the decision was based on the Commission Guidelines issued in 2002 and since they had not been published in Polish in the Official Journal of the European Union, they could not be relied on against PTC (as a private company). The PTC's action failed in two instances and subsequently the company lodged a cassation to the Polish Supreme Court (Sad Najwyższy). The Supreme Court carefully examined the case law of the CJEU concerning the publication of legal acts and the binding effects on individuals (including the Skoma-Lux case, analysed earlier) and questioned the effects of the Commission Guidelines. The Supreme Court wondered whether the term 'obligations contained in Community legislation', used in para. 51 of Skoma-Lux, covered (apart from regulations and decisions) also other acts of EU institutions affecting individuals' rights or obligations and noted that the CJEU's jurisprudence justified a conclusion that this term is interpreted rather broadly. ${ }^{124}$ The Court observed that the Guidelines gave rise to legitimate legal expectations on the part of persons whose situation falls within their scope. ${ }^{125}$ Moreover, the Supreme Court concluded that in these circumstances Polish telecommunications undertakings were in a less favourable situation than undertakings established in other Member States, which were able to acquaint themselves with the guidelines in the official languages of those States. ${ }^{126}$ For these reasons the Supreme Court decided to refer to the CJEU a question concerning the legal effects of the unpublished Guidelines. The Court of Justice in its reply first reiterated that a fundamental principle of the EU's legal order (principle of legal certainty - A.Cz.) required that measures adopted by the public authorities could not be enforceable against the persons concerned before they have had an opportunity to acquaint themselves with such rules. In addition, as it had been stated in Skoma-Lux, the Act of Accession to the EU of i.a. Poland precluded the obligations provided for in EU legislation, which had not been published in the Official Journal in the language of a new Member State (and that language being an official language of the EU), from being imposed on individuals in that State, even though those persons could have accessed the content of that legislation by other

122 Guidelines on market analysis and the assessment of significant market power under the Community regulatory framework for electronic communications networks and services, O.J. C 16520026.

123 Art. 16 of the Directive 2002/21.

124 Case C-410/09 Polska Telefonia Cyfrowa, paras 17, 19.

125 Ibidem, para. 20.

126 Ibidem, para. 18. 
means. ${ }^{127}$ Addressing the considerations raised by the Supreme Court, the CJEU pointed out that the character of the Guidelines is to be evaluated on the basis of their content, which justified the conclusion that they could impose obligations on individuals. In that respect the CJEU, after a thorough examination, observed that the guidelines merely set out the principles that the NRAs should use in the analysis of markets and effective competition under the regulatory framework for electronic communications. ${ }^{128}$ Consequently, the Court of Justice concluded that the Guidelines did not contain any obligation capable of being imposed, directly or indirectly, on individuals and thus the fact that they had not been published in the Official Journal in Polish did not prevent the Polish NRA from referring to them in a decision addressed to an individual.

The Polska Telefonia Cyfrowa ruling constitutes one of the best examples of a dialogue approach on the part of both involved courts. The referring Supreme Court presented a well-elaborated set of arguments for consideration of the CJEU with a thorough reference to the latter's jurisprudence on the issue. The Court of Justice comprehensively addressed all the doubts and points presented by the referring court. As the result, a ruling was issued, which truly develops the doctrine of EU sources of law and legal effects of sui generis acts.

The case Rubach demonstrates that, sometimes, unusual motivations stand behind a national court's decision to make a preliminary reference and to enter the judicial dialogue. ${ }^{129}$ The case before the national District Court in Kościan (Sad Rejonowy) concerned the criminal proceedings against Mr. T. Rubach. He acquired at a terrarium fair the exotic spiders of the genus Brachypelma Albopilosum, which is a protected specimen listed in Annex B to Regulation 338/97. ${ }^{130}$ The inclusion in the Annex prohibits effectively commercial activities with regard to such specimen, except where it can be proved that such specimens were acquired and introduced into the EU, in accordance with the legislation in force for the conservation of wild fauna and flora. ${ }^{131} \mathrm{Mr}$. Rubach began breeding those spiders in captivity and auctioning them on the internet between February and October 2006. On the basis of those facts, he was charged with 46 infringements of Art. 128 the Polish Law on nature protection, which penalized i.a. infringements "of the provisions of EU law concerning the protection of species of wild animals and plants through the regulation of trade therein by: [...] (d) offering for sale or purchase, purchasing or acquiring, using or displaying publicly for commercial purposes, selling, holding or transporting for the purpose of sale, specimens of specific species of plants or animals." In October 2007, the District Court in Kościan acquitted the accused of all the charges because,

127 Ibidem, paras 23-24.

128 Ibidem, para. 30.

129 Case C-344/08 Criminal proceedings against Tomasz Rubach (CJEU, 16 July 2009).

130 Council Regulation (EC) 338/97 of 9 December 1996 on the protection of species of wild fauna and flora by regulating trade therein, O.J. L 6119971.

131 Art. 8 of the Regulation 338/97. 
in the Court's view, his actions did not constitute the prohibited act. However the district prosecutor appealed against the first instance judgement and the appellate court, the Provincial Court (Sąd Okręgowy) in Poznań, overturned that judgment in its entirety and referred the case for reconsideration back to the District Court. ${ }^{132}$

While reconsidering the case, the District Court observed that appellate court's interpretation of national law, which was binding on the District Court, actually meant that the accused could avoid criminal liability, only if he were in a position to establish the source of the animals, either by producing a certificate of registration (as required under Article 64(1) of the Law on nature protection) relating to the animals sold or by supplying evidence which would make it possible to retrace the source of those animals and to identify with certainty the previous owner or breeder. However, according to the court's investigations, the accused was unable to register the spiders because, as arachnids, they were not subject to registration under Polish law. As the court pointed out, Mr. Rubach was not required under Polish law to have any specific knowledge of the origin of the animals that he had bought, since he had bought them at a legal fair. In the District Court's view, Mr. Rubach, as unable to produce any of the evidence required by the appellate court, could not avoid criminal liability. Therefore, the District Court decided to refer a question to the Court for a preliminary ruling:

[H]ow, under [Article 8(5) of Regulation No. 338/97] and in the light of the presumption of innocence, may a keeper of animals listed in Annex B [to that regulation] (which are not amphibians, reptiles, birds or mammals) prove satisfactorily that his specimens were acquired $[\ldots]$ in accordance with the legislation in force with regard to wild fauna and flora $[\ldots]$ ?

The CJEU considered the question very thoroughly. It observed, first, that Regulation 338/97 did not limit the evidence that might be used in order to establish that specimens of species listed in Annex B to that regulation have been acquired lawfully and the apportionment of the burden of proof should be assessed in the light of the principle of the presumption of innocence which is one of the fundamental rights protected in the EU legal order (the Court referred to its case law but also to Art. 6 ECHR). ${ }^{133}$ Accordingly the CJEU reminded that introduction of the system of protection for specimens of species listed in Annexes A and B to Regulation No. 338/97 did not in any way affect the general obligation of the prosecution to prove that the criminal act had occurred. ${ }^{134}$ Consequently, the CJEU ruled that Art. 8(5) of Regulation 338/97 had to be interpreted as

132 Case C-344/08 Rubach, para. 12.

133 Ibidem, paras 29-30.

134 Ibidem, para. 32. 
meaning that, in the context of criminal proceedings brought against a person accused of having infringed that provision, any type of evidence accepted under the procedural law of the Member State concerned in similar proceedings is in principle admissible for the purpose of establishing whether specimens of animal species listed in Annex B to that regulation were lawfully acquired. In the light also of the principle of the presumption of innocence, such a person may adduce any such evidence to prove that those specimens came lawfully into his possession in accordance with the conditions laid down in that provision. ${ }^{135}$

It is not hard to agree with the opinion that the Rubach case is quite unique in that it demonstrates that the preliminary ruling procedure can be used as remedy against mistakes of other courts. Also in that, it shows exceptional engagement of the referring court, which did all that was possible, or even more, to ensure that the rights of an individual - including such fundamental principle as presumption of innocence - are observed despite the curious findings of the court of higher instance. This is the 'human face' of judicial dialogue.

\section{Conclusion}

The presented selection of preliminary rulings on the questions referred by the courts of Czech Republic, Hungary, Lithuania and Poland contains the ones that are most significant for the development of EU law. Although the number of preliminary references originating from the CEE States subject to research is - with the exception of Hungary - lower than the EU average, there are no differences as to the quality of the references. The problems of interpretation of EU law (the questions on validity are scarce) raised by the national courts in their preliminary references concern matters fundamental from the constitutional perspective of the EU legal order as well as issues essential from the point of view of development of the particular domains of EU law. Quite often national courts show courage to present, beside the factual and legal circumstances of the cases pending before them, their own considerations on the problems that are subject of preliminary references. This way they open the field to discussion and contribute to the enrichment of judicial dialogue. This practice seems to be welcome by the CJEU, as the examined case law leaves the impression that the Court is interested and inspired to develop the judicial dialogue where it has the opportunity to engage in a 'correspondence' discussion of sorts with arguments of the national courts. In its replies the CJEU tries to be as unequivocal as possible as to the interpretation of norms of EU law, but, as a rule, it leaves to national courts a wide

135 Ibidem, para. 34. 
margin of discretion in the assessment whether and in what way the interpretation given may be applied in national proceedings. As the result, we may conclude that also in the context of the CEE States the institutionalised judicial dialogue, organised with a use of the preliminary reference, constitutes an excellent means of creation and sustainable development of international, supra-State legal order where, at the same time, the common Union interest, the rights of individuals and the national identities of the Member States are protected. 


\section{Bibliography}

\section{Case-law}

\section{CJEU}

283/81 Srl CILFIT and Lanificio di Gavardo SpA v Ministry of Health (6 October 1982)

160/84 Oryzomyli Kavallas and Others (15 May 1986)

C-453/00 Kühne \& Heitz NV v Produktschap voor Pluimvee en Eieren (13 January 2004)

C-302/04 Ynos kft v János Varga (10 January 2006)

C-2/06 Willy Kempter KG v Hauptzollamt Hamburg-Jonas (12 February 2008)

C-2/06 Willy Kempter KG v Hauptzollamt Hamburg-Jonas (Advocate General Y. Bot opinion, 24 April 2007)

C-161/06 Skoma-Lux sro $v$ Celní ředitelství Olomouc (11 December 2007)

C-210/06 Cartesio Oktató és Szolgáltató bt (16 December 2008)

C-239/07 Julius Sabatauskas and Others (9 October 2008)

C-404/07 György Katz v István Roland Sós (9 October 2008)

C-314/08 Krzysztof Filipiak v Dyrektor Izby Skarbowej w Poznaniu (19 November 2009)

C-344/08 Criminal proceedings against Tomasz Rubach (16 July 2009)

C-31/09 Nawras Bolbol v Bevándorlási és Állampolgársági Hivatal (17 June 2010)

C-399/09 Marie Landtová v Česká správa socialního zabezpečení (22 June 2011)

C-378/10 VALE Épitési Kft. (12 July 2012)

C-410/09 Polska Telefonia Cyfrowa sp. z o.o. v Prezes Urzędu Komunikacji Elektronicznej (12 May 2011)

C-254/11 Szabolcs-Szatmár-Bereg Megyei Rendörkapitányság Záhony Határrendészeti Kirendeltsége $v$ Oskar Shomodi (21 March 2013)

C-364/11 Mostafa Abed El Karem El Kott and Others v Bevándorlási és Állampolgársági Hivatal (19 December 2012)

C-314/13 Užsienio reikalų ministerija and Finansiniu nusikaltimu tyrimo tarnyba $v$ Vladimir Peftiev and Others (12 June 2014)

C-536/13 Gazprom OAO v Lietuvos Respublika (13 May 2015)

\section{National courts}

\section{Czech Republic}

III. ÚS 252/04 (Czech Constitutional Court, judgment, 25 January 2005)

PI. ÚS 5/12, Slovak Pensions XVII (Czech Constitutional Court, judgment, 31 January 2012)

\section{Poland}

K 18/06 (Polish Constitutional Court, 7 November 2007) 


\section{References}

\section{Books}

Alter K., Establishing the Supremacy of European Law: The Making of an International Rule of Law in Europe (Oxford University Press 2001)

Broberg M., Fergen N., Preliminary References to the European Court of Justice (Oxford University Press 2014)

Martinico G., Pollicino O., The Interaction between Europe's Legal Systems. Judicial Dialogue and the Creation of Supranational Laws (Edward Elgar Publishing 2012)

\section{Book Sections}

Arnull A., 'Judicial Dialogue in the European Union”, [in:] Dickinson J., Eleftheriadis P. (eds), Philosophical Foundations of European Union Law (Oxford University Press 2012) 109

Tridimas T., 'The CJEU and the Specifity of Preliminary Reference Rulings: Some Reflections', [in:] Besson S., Pichonnaz P. (eds), Les principes de droit européen - Principles in European Law (L.G.D.J. 2011) 331

\section{Articles}

Carruba C., Murrah L., 'Legal Integration and Use of the Preliminary Ruling Process in the European Union' (2005) 59 International Organization 399

Cartabia M., 'Taking Dialogue Seriously The Renewed Need for a Judicial Dialogue at the Time of Constitutional Activism in the European Union' (2007) 12 Jean Monnet Working Papers

Claes M., Visser de M., 'Are You Networked Yet? On Dialogues in European Judicial Networks' (2012) 8 Utrecht Law Review 100

Cohen J., 'The European Preliminary Reference and the US Supreme Court Review of State Court Judgments: A Study in Comparative Judicial Federalism' (1996) 44 AJIL 421

Dyevre A., 'Domestic Judicial Non-Compliance in the European Union: A Political Economic Approach' (2013) 2 LSE Law, Society, Economy Working Papers

Farrell Miller A., 'The Preliminary Reference Procedure of the Court of |Justice of the European Communities: A Model for the ICJ' (2009) 32 Hastings International and Comparative Law Review 669

Fennely N., 'Preliminary Reference Procedure: A Factual and Legal Review' (2006) 13 Irish Journal of European Law 55

Jacobs F., 'Judicial dialogue and the Cross-Fertilization of Legal Systems: The European Court of Justice' (2003) 38 Texas International Law Journal 547

Kelemen R.D., 'The Court of Justice of the European Union in the Twenty-First Century' (2016) 79 Law and Contemporary Problems 117

Tremblay L., 'The Legitimacy of Judicial Review: The Limits of Dialogue between Courts and Legislatures' (2005) 3 International Journal of Constitutional Law 617

Virzo R., 'The Preliminary Ruling Procedures at International Regional Courts and Tribunals' (2011) 10 The Law and Practice of International Courts and Tribunals 285 


\section{Other}

Convention implementing the Schengen Agreement of 14 June 1985 between the Governments of the States of the Benelux Economic Union, the Federal Republic of Germany and the French Republic on the gradual abolition of checks at their common borders, signed at Schengen on 19 June 1990, O.J. L 239200019

Council document 11679/07 EU of 9 July 2007 "Best Practices for the effective implementation of restrictive measures", <http://register.consilium.europa.eu/doc/srv?l=EN\&f=ST\%2011679\%20 2007\%20INIT> (access: 5 April 2017)

Council Regulation (EC) 338/97 of 9 December 1996 on the protection of species of wild fauna and flora by regulating trade therein, O.J. L 6119971

Council Regulation (EU) No. 216/2013 of 7 March 2013 on the electronic publication of the Official Journal of the European Union O.J. L 6920131

Guidelines on market analysis and the assessment of significant market power under the Community regulatory framework for electronic communications networks and services, O.J. C 16520026

Official video records of the international colloquy, 'La concurrence des juges en Europe - le dialogue en question(s)' (Tours, 25-27 November 2015), <https://juges-en-europe.sciencesconf.org/ resource/page/id/10> (access: 10 June 2016)

Regulation (EC) 1931/2006 of the European Parliament and of the Council of 20 December 2006 laying down rules on local border traffic at the external land borders of the Member States and amending the provisions of the Schengen Convention, O.J. L 4052006 1, corrigendum O.J. L 2920073

Regulation No. 1 determining the languages to be used by the European Economic Community, O.J. 171958 385, last amended by Council Regulation (EU) 517/2013 of 13 May 2013, O.J. L 158 20131

Rules of Procedure of the Court of Justice of 25 September 2012, O.J. L 2652012 1, as amended on 18 June 2013, O.J. L 173201365 